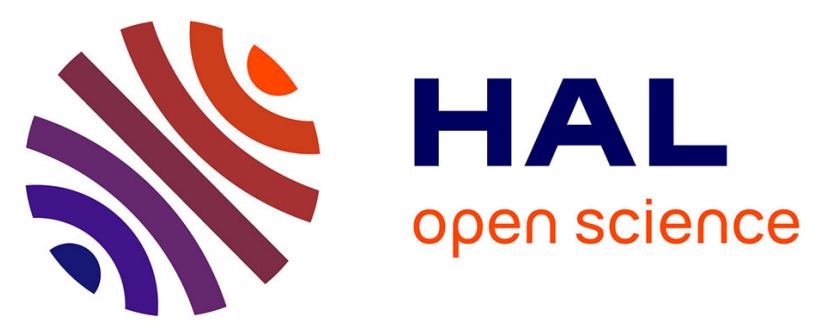

\title{
Ordered mesoporous silicon carbide-derived carbon for high-power supercapacitors
}

Wan-Yu Tsai, Peng-Cheng Gao, Barbara Daffos, Pierre-Louis Taberna, Carlos R. Pérez, Yury Gogotsi, Frédéric Favier, Patrice Simon

\section{To cite this version:}

Wan-Yu Tsai, Peng-Cheng Gao, Barbara Daffos, Pierre-Louis Taberna, Carlos R. Pérez, et al.. Ordered mesoporous silicon carbide-derived carbon for high-power supercapacitors. Electrochemistry Communications, 2013, vol. 34, pp. 109-112. 10.1016/j.elecom.2013.05.031 . hal-01154291

\author{
HAL Id: hal-01154291 \\ https://hal.science/hal-01154291
}

Submitted on 21 May 2015

HAL is a multi-disciplinary open access archive for the deposit and dissemination of scientific research documents, whether they are published or not. The documents may come from teaching and research institutions in France or abroad, or from public or private research centers.
L'archive ouverte pluridisciplinaire HAL, est destinée au dépôt et à la diffusion de documents scientifiques de niveau recherche, publiés ou non, émanant des établissements d'enseignement et de recherche français ou étrangers, des laboratoires publics ou privés. 


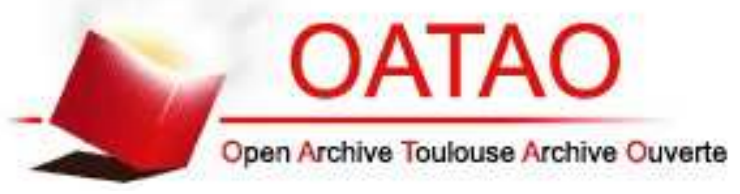

\section{Open Archive TOULOUSE Archive Ouverte (OATAO)}

OATAO is an open access repository that collects the work of Toulouse researchers and makes it freely available over the web where possible.

This is an author-deposited version published in : http://oatao.univ-toulouse.fr/ Eprints ID : 13895

To link to this article : DOI:10.1016/j.elecom.2013.05.031

URL : http://dx.doi.org/10.1016/j.elecom.2013.05.031

\section{To cite this version :}

Tsai, Wan-Yu and Gao, Peng-Cheng and Daffos, Barbara and Taberna, Pierre-Louis and Pérez, Carlos R. and Gogotsi, Yury and Favier, Frédéric and Simon, Patrice Ordered mesoporous silicon carbide-derived carbon for high-power supercapacitors. (2013) Electrochemistry Communications, vol. 34. pp. 109-112. ISSN $1388-2481$

Any correspondance concerning this service should be sent to the repository administrator: staff-oatao@ listes-diff.inp-toulouse.fr 


\title{
Ordered mesoporous silicon carbide-derived carbon for high-power supercapacitors
}

\author{
Wan-Yu Tsai a,b, Peng-Cheng Gao ${ }^{\text {b,c }}$, Barbara Daffos ${ }^{\text {a,b }}$, Pierre-Louis Taberna ${ }^{\text {a,b }}$, Carlos R. Perez ${ }^{\text {d }}$, \\ Yury Gogotsi ${ }^{\mathrm{d}}$, Frederic Favier ${ }^{\mathrm{b}, \mathrm{c}, *}$, Patrice Simon ${ }^{\mathrm{a}, \mathrm{b}, * *}$ \\ a Université Paul Sabatier, CIRIMAT UMR CNRS 5085, 118 route de Narbonne, 31062 Toulouse, France \\ ${ }^{\mathrm{b}}$ Réseau sur le Stockage Electrochimique de l'Energie (RS2E), FR CNRS 3459, France \\ ${ }^{c}$ Institut Charles Gerhardt Montpellier, UMR 5235 CNRS, Université Montpellier 2, cc1502, 34095 Montpellier cedex 05, France \\ d Department of Materials Science and Engineering E' A.J. Drexel Nanotechnology Institute, Drexel University, 3141 Chestnut St., Philadelphia, PA 19104, United States
}

Keywords:

\begin{abstract}
A B S T R A C T
Micro/mesoporous carbon was prepared by chlorination of ordered mesoporous silicon carbide derived from magnesio-thermal reduction of templated carbon-silica precursors. These materials were then used as active materials for electrochemical capacitors and characterized in $1.5 \mathrm{M} \mathrm{NEt}_{4} \mathrm{BF}_{4} / \mathrm{AN}$. The electrodes showed outstanding rate capability (90\% of capacity retention at $1 \mathrm{~V} / \mathrm{s}$ and time constant of $1 \mathrm{~s}$ ) with high specific areal capacitance $\left(0.5 \mathrm{~F} / \mathrm{cm}^{2}\right.$ of electrode), that makes such hierarchical porous carbons promising for high power and energy density supercapacitors.
\end{abstract}

Supercapacitors

Carbon

Hierarchical porosity

Magnesio-thermal reduction

Power density

\section{Introduction}

Electrochemical double layer capacitors (EDLCs), also known as supercapacitors, store charge by simple electrostatic attraction between electrolyte ions and charges at the electrode surface. Due to a different nature of energy storage, supercapacitors hold higher power density $(15 \mathrm{~kW} / \mathrm{kg})$ and much better cyclability $\left(>10^{6}\right)$ as compared to batteries [1,2].

Carbon-based materials with high specific surface area (SSA) have been widely studied as supercapacitor electrodes due to their chemical stability and high conductivity. While activated carbon is the material of choice for commercial supercapacitors, carbide derived carbons (CDCs) [3], onion-like carbons (OLCs) [4,5], carbon nanotubes (CNTs) [6], and graphene [7] have also been investigated. Among those, microporous CDCs are highly attractive thanks to their tunable structure leading to high capacitance and high power capabilities [8-10]. CDCs are prepared by chlorination of metal carbides; depending on the choice of precursor material and synthesis conditions, the resulting microstructure can be nicely controlled with a narrow pore size

* Correspondence to: F. Favier, Institut Charles Gerhardt Montpellier, UMR 5235 CNRS, Université Montpellier 2, cc1502, 34095 Montpellier cedex 05, France. Tel.: + 3346714 3332.

** Correspondence to: P. Simon, Université Paul Sabatier, CIRIMAT UMR CNRS 5085, 118 route de Narbonne, 31062 Toulouse, France. Tel.: +33561556802.

E-mail addresses: fredf@um2.fr (F. Favier), simon@chimie.ups-tlse.fr (P. Simon). distribution, while retaining the original carbide shape and volume (a conformal transformation) [3]. We recently developed an original route for the synthesis of ordered mesoporous carbides by a magnesiothermal reaction on silica-carbon mesoporous composites [11]. The present work investigates the electrochemical performance of such ordered micro/mesoporous silicon carbide-CDC (SiC-CDC) materials in supercapacitor applications.

\section{Experimental}

\subsection{Synthesis of SiC-CDC}

Mesoporous carbon-silica composites were prepared with slight modifications of the synthetic route described by Liu et al. [12]. A triblock copolymer P123 (Aldrich) was chosen as soft template. In a typical procedure, under vigorous stirring, $1 \mathrm{~g}$ of $0.2 \mathrm{M} \mathrm{HCl}$ was added to $9.6 \mathrm{~g}$ of $20 \mathrm{wt} . \%$ P123 alcoholic solution. After stirring at $40{ }^{\circ} \mathrm{C}$ for $4 \mathrm{~h}$, a clear solution was obtained. Subsequently, $2.5 \mathrm{~g}$ of $20 \mathrm{wt}$ \% resol alcoholic solution and $2.08 \mathrm{~g}$ tetraethoxysilane (TEOs, 98\% Alfa Aesar) were added. The mixture was continuously stirred for $2 \mathrm{~h}$ and painted afterwards onto a glass plate. The resulting film was kept at ambient temperature overnight to evaporate residual ethanol before being polymerized at $100{ }^{\circ} \mathrm{C}$ for $24 \mathrm{~h}$. The as-made film was scraped and ground into fine powder before being carbonized in a tube furnace at $800{ }^{\circ} \mathrm{C}$ for $3 \mathrm{~h}$ under $\mathrm{N}_{2}$ flow. C/Si molar 

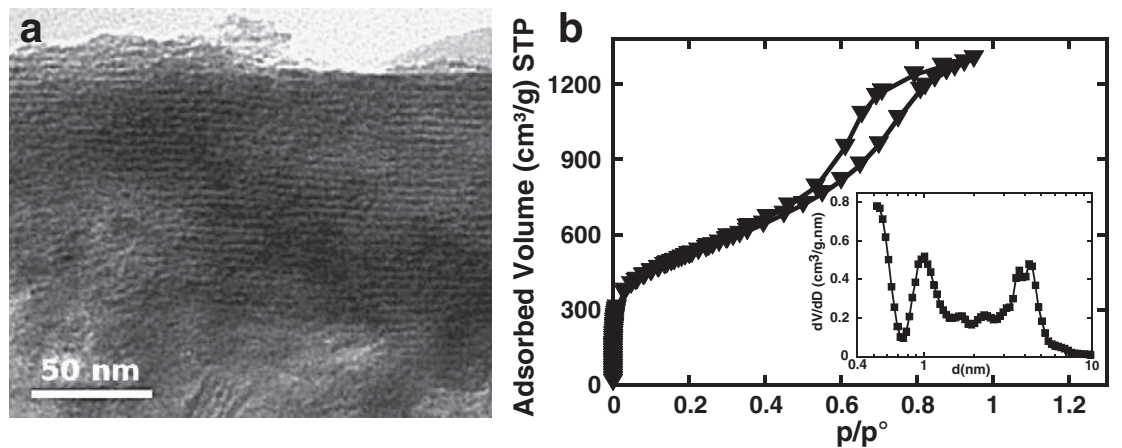

Fig. 1. TEM image of SiC-CDC (a) and gas adsorption/desorption isotherms of SiC-CDC (SSA $1619 \mathrm{~m}^{2} / \mathrm{g}$ ); inset shows the pore size distribution of the SiC-CDC powder derived from QSDFT (b).

ratio was measured at 1.04:1 by residual silica content after burning $\mathrm{SiC}$ precursors at $550{ }^{\circ} \mathrm{C}$ for $2 \mathrm{~h}$.

The mesoporous silicon carbide was synthesized by using $\mathrm{Mg}$ as reducing agent at moderate temperatures as described in our recent work [11]. After sealing a carbon $/ \mathrm{SiO}_{2}$ composite mixed with $\mathrm{Mg}$ powder $\left(10 \% \mathrm{Mg}\right.$ molar excess over $\left.\mathrm{SiO}_{2}\right)$ under $\mathrm{Ar}$ in a $316 \mathrm{~L}$ stainless steel tube, the magnesio-thermal reduction was performed at $800{ }^{\circ} \mathrm{C}$ for $24 \mathrm{~h}$ at a heating rate of $1{ }^{\circ} \mathrm{C} / \mathrm{min}$. $\mathrm{SiC}$ product was purified using $1 \mathrm{M} \mathrm{HCl}$ and $1 \mathrm{M} \mathrm{HNO}_{3}$ aqueous solutions in sequence.

$\mathrm{CDC}$ powders were produced by chlorination of the $\mathrm{SiC}$ precursor, as previously described [3]. The precursor was placed in a horizontal tube furnace and heated to $800{ }^{\circ} \mathrm{C}$ in $\mathrm{Ar}$, followed by $\mathrm{Cl}_{2}$ flow (10$15 \mathrm{~cm}^{3} / \mathrm{min}$ ) for $3 \mathrm{~h}$. After flushing residual $\mathrm{Cl}_{2}$ with $\mathrm{Ar}$ and lowering the temperature to $600{ }^{\circ} \mathrm{C}$, the sample was annealed for $2 \mathrm{~h}$ using $\mathrm{H}_{2}$.

\subsection{Material characterization}

Transmission electron microscopy (TEM) images were obtained using a JEOL 1200 EX2 TEM operating at $100 \mathrm{kV}$. Porosity characteristics were calculated from argon sorption isotherms measured at $87 \mathrm{~K}$ with Micromeritics ASAP 2020 porosimeter. The specific surface area was estimated by using both Brunauer-Emmett-Teller (BET) and density functional theory (DFT) method while the pore volumes and the pore size distributions were calculated from adsorption isotherms by using quenched solid density functional theory (QSDFT) method [13].

\subsection{Electrochemical characterization}

SiC-CDC electrode films were prepared by mixing 95 wt.\% of SiC-CDC powder with $5 \mathrm{wt}$ \%\% of polytetrafluoroethylene (PTFE; $60 \mathrm{wt}$ \% dispersion in water) using ethanol as the medium for mixing the slurry.

a

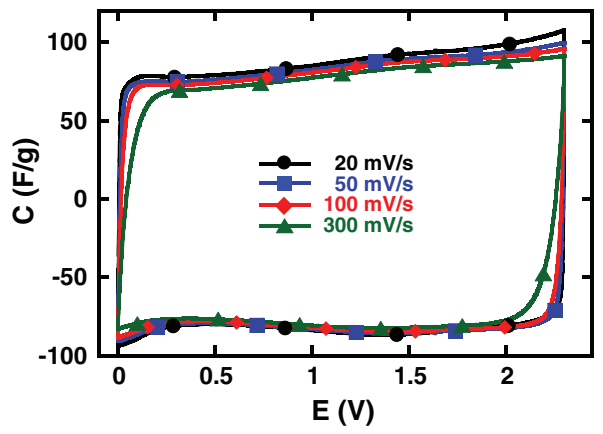

Electrode film thickness was about $210 \mu \mathrm{m}$ and the SiC-CDC loading was $7.3 \mathrm{mg} / \mathrm{cm}^{2}$, close to that of commercial electrodes $(100-200 \mu \mathrm{m}$ or about $10 \mathrm{mg} / \mathrm{cm}^{2}$ ) [14], leading to an apparent electrode density of $0.35 \mathrm{~g} / \mathrm{cm}^{3}$. Electrochemical characterization of SiC-CDC electrodes was conducted in $1.5 \mathrm{M}$ tetraethylammonium tetrafluoroborate $\left(\mathrm{NEt}_{4} \mathrm{BF}_{4}\right)$ (Acros Organics, CAS \#429-06-1) in acetonitrile (AN) (Acros Organics, CAS \#75-05-8, $\mathrm{H}_{2} \mathrm{O}<10 \mathrm{ppm}$ ) in a two-electrode Swagelok cell [15] assembled in a glove box under argon atmosphere, at room temperature. The electrode films were laminated onto treated aluminum current collectors [8], and two layers of $25 \mu \mathrm{m}$-thick porous cellulose were used as separator.

Cyclic voltammetry (CV) tests at various scan rates were performed between 0 and $2.3 \mathrm{~V}$. Electrochemical impedance spectroscopy (EIS) measurements were performed at the rest potential, using a sinusoidal signal of $\pm 5 \mathrm{mV}$ from $50 \mathrm{kHz}$ to $10 \mathrm{mHz}$. Electrochemical tests were performed using a multichannel VMP3 potentiostat/galvanostat (BioLogic, France).

\section{Results and discussion}

The TEM image, gas adsorption/desorption isotherm and the pore size distribution obtained from QSDFT (Fig. 1) show that the mesoporous structure of the silicon carbide was retained after chlorination, with a significant fraction ( $30 \%)$ of the pores having sizes greater than $2 \mathrm{~nm}$. Additionally, the SiC-CDC contains narrowly distributed micropores as a peak at $1 \mathrm{~nm}$ is observed in Fig. $1 \mathrm{~b}$ (inset). The specific surface areas of SiC-CDC calculated from BET method and DFT method are $1619 \mathrm{~m}^{2} / \mathrm{g}$ and $1335 \mathrm{~m}^{2} / \mathrm{g}$, respectively.

Fig. 2a shows cyclic voltammograms of the $\mathrm{SiC}-\mathrm{CDC}$ at various scan rates from 20 to $300 \mathrm{mV} / \mathrm{s}$ in $1.5 \mathrm{M} \mathrm{NEt}_{4} \mathrm{BF}_{4}$ in AN electrolyte. All the CVs exhibit a rectangular shape, which is characteristic of a pure

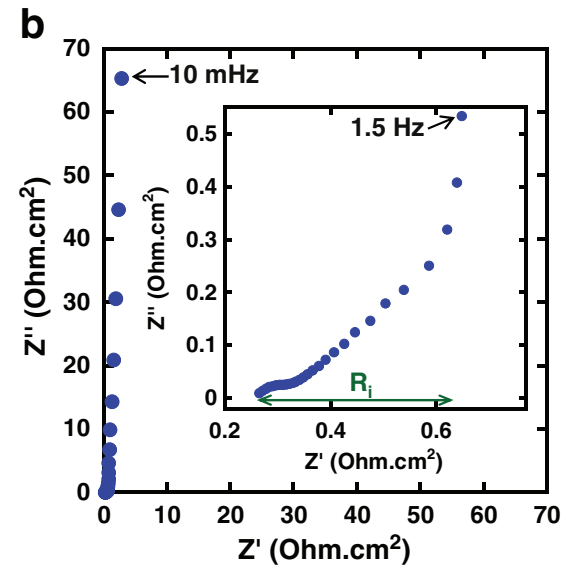

Fig. 2. Electrochemical characterization of Si-CDC in $1.5 \mathrm{M} \mathrm{NEt}_{4} \mathrm{BF}_{4}$ /acetonitrile: $\mathrm{CVs}$ at different scan rates (a) and the corresponding EIS Nyquist plot (b). Inset in (b) shows data in the high-frequency range $\left(\mathrm{R}_{\mathrm{i}}=\right.$ ionic resistance). 
a

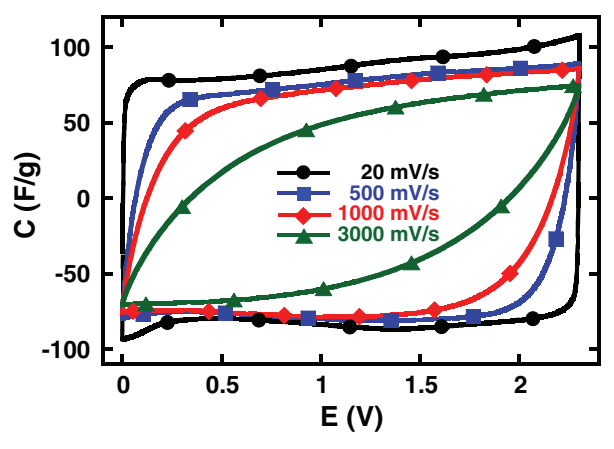

b

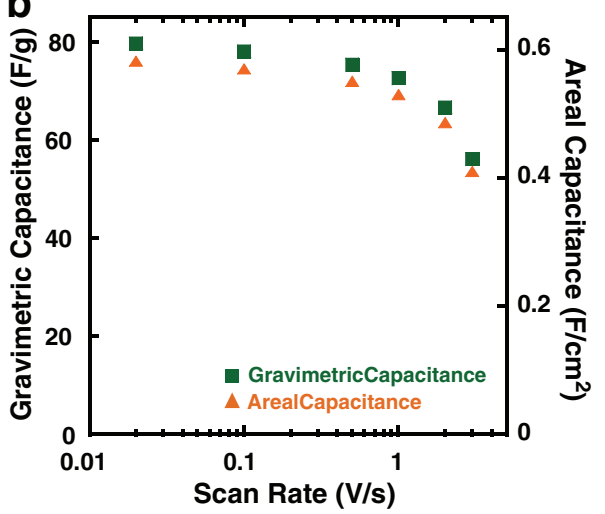

Fig. 3. CVs at scan rates up to $3 \mathrm{~V} / \mathrm{s}$ (a) and capacitance vs. scan rate (b).

capacitive behavior. When the potential scan rate increased, the rectangular profile was nicely preserved up to $300 \mathrm{mV} / \mathrm{s}$, although a slight distortion appeared when the potential was switched back. The perfect symmetry in the distortion evidences an ohmic origin, which is linked to the ohmic drop in the bulk electrolyte. The specific capacitance of the prepared porous carbon is $80 \mathrm{~F} / \mathrm{g}$. This value is certainly not among the highest reported in the literature for porous carbons in organic electrolyte [16]; however, taking into account the carbon weight loading of $7.3 \mathrm{mg} / \mathrm{cm}^{2}$, it corresponds to a specific capacitance of more than $0.5 \mathrm{~F} / \mathrm{cm}^{2}$ per electrode, which is far beyond most values reported in the literature $[4,6,17,18]$ at the same scan rate. The specific capacitance per $\mathrm{cm}^{2}$ of the electrode is representative to the energy that could be stored in a real device [14].

The EIS Nyquist plot of the cell (Fig. 2b) shows a typical capacitive behavior of a porous blocking electrode [19] as well as an extremely low resistance: an equivalent series resistance (ESR) of $0.25 \Omega \mathrm{cm}^{2}$ and an ionic resistance of the electrolyte inside the porous carbon electrode of $0.35 \Omega \mathrm{cm}^{2}$. Both ESR and ionic resistance obtained are smaller than those found in the literature for other carbon-based materials (activated carbon [19], other CDCs [20], CNT [4], carbon onion [4], graphene [7]) in the same electrolyte under similar testing conditions. While micropores provide a good charge storage capability, a high power is anticipated from the low intrinsic resistance of SiC-CDC and high ion accessibility through the mesopores.

Fig. 3a shows CVs at high scan rates from 20 to $3000 \mathrm{mV} / \mathrm{s}$ and Fig. 3b shows the gravimetric capacitance (derived from the slope of the Q-V curve during cell discharge) and the areal capacitance (obtained by dividing the electrode capacitance by the geometric area of the cell) as a function of the potential scan rate. The capacitive $\mathrm{CV}$ shape was preserved up to $1 \mathrm{~V} / \mathrm{s}$, with a gravimetric capacitance of $75 \mathrm{~F} / \mathrm{g}$, corresponding to $>90 \%$ of capacitance retention; this already evidences the high power performance of the material.

The frequency behavior of the cell was analyzed using a complex capacitance model [19], based on the modeling of the capacitance in real part $C^{\prime}(\omega)$ and imaginary part $C^{\prime \prime}(\omega)$, both functions of the frequency. Fig. 4a shows the change of the real part of the capacitance $C^{\prime}(\omega)$ with frequency. The graph shows a transition from purely resistive behavior at high frequency (phase angle close to 0 ) to purely capacitive behavior at low frequency (phase angle of $-87^{\circ}$ ). The whole capacitance of the electrode is reached at around $0.2 \mathrm{~Hz}$ since a plateau at high frequency is observed; the capacitance value for a phase angle of $-45^{\circ}$ obtained at $1 \mathrm{~Hz}$ is $0.25 \mathrm{~F} / \mathrm{cm}^{2}$. This corresponds to half of the total capacitance of the electrode [19]. The change of $\mathrm{C}^{\prime}$ vs. frequency first evidences the high power capability of the prepared porous carbon, since the transition frequency is high, at $1 \mathrm{~Hz}$. Higher power can be reached using thin films in microdevices for instance, or exohedral carbons with accessible but limited surface area. However, it is achieved at the expense of the energy density. As such, the areal capacitance $\left(\mathrm{F} / \mathrm{cm}^{2}\right)$ of such devices or electrodes is low, from $\mu \mathrm{F} / \mathrm{cm}^{2}$ to few $\mathrm{mF} / \mathrm{cm}^{2}[17,18,21,22]$. In contrast, thanks to the hierarchical porous structure of the SiC-CDC prepared in this work, an attractive areal capacitance of $0.5 \mathrm{~F} / \mathrm{cm}^{2}$ was obtained, demonstrating a higher energy density.

Fig. $4 \mathrm{~b}$ shows the imaginary part of the capacitance, $C^{\prime \prime}(\omega)$, vs. frequency. The relaxation time $\tau_{0}$ in this system is $1 \mathrm{~s}$, which can be calculated from $\tau_{0}=1 / f_{0}$, where $f_{0}$ is the frequency corresponding to the maximum of the curve of $C^{\prime \prime} v s$. $f$. These micro/mesoporous carbons thus show high power performance with high specific
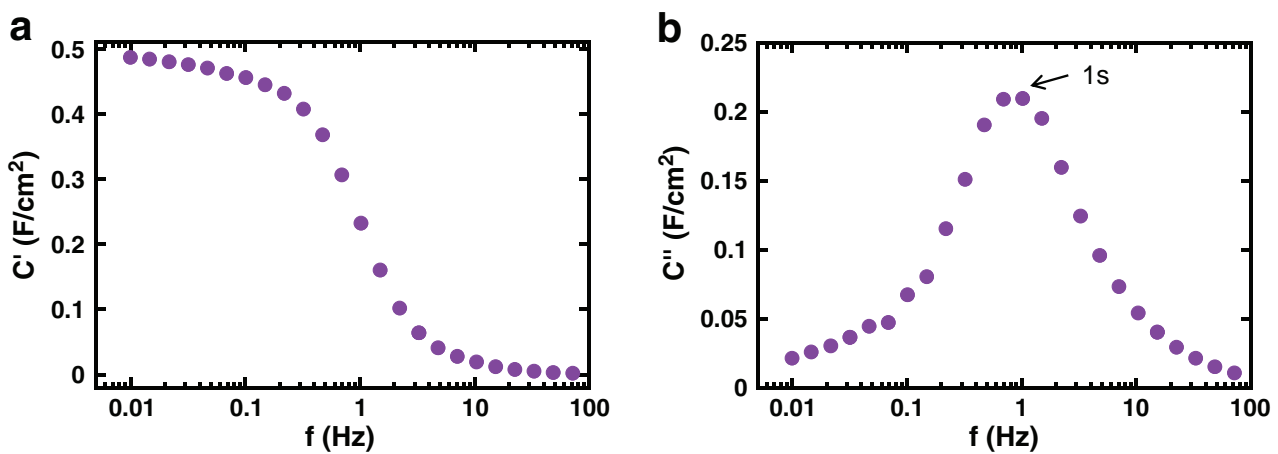

Fig. 4. Real capacitance, $C^{\prime}$ (a) and imaginary capacitance, $C^{\prime \prime}$ (b) vs. the logarithm of frequency. 
capacitance. These results suggest that the magnesio-thermal reduction of $\mathrm{SiC}$ is an efficient way for producing carbon for high power applications when high energy density is also required.

\section{Conclusions}

Evaluation of the ordered mesoporous SiC-CDC as an electrode material for supercapacitors was done in $1.5 \mathrm{M} \mathrm{NEt}_{4} \mathrm{BF}_{4} / \mathrm{AN}$ electrolyte, giving respectable gravimetric capacitance $(80 \mathrm{~F} / \mathrm{g}$ ), and high capacity retention up to $1 \mathrm{~V} / \mathrm{s}$, a high rate compared to other high-SSA porous carbons. EIS study showed a low intrinsic resistance of CDC, high ion accessibility to the micro/mesoporous hierarchical structure, and thus a remarkably low relaxation time of the system, evidencing that the use of such hierarchical porous carbons for high power supercapacitors is very promising.

\section{Acknowledgments}

P.C.G. would like to thank the Chinese Scientific Council for fellowship. W.-Y.T. was supported by the European Research Council (ERC, Advanced Grant, ERC-2011-AdG, Project 291543 - IONACES). P.S. acknowledges the funding from the Chair of Excellence of the EADS foundation "Embedded multi-functional materials". C.P. and Y.G. are thankful to the U.S. Department of Energy, Office of Basic Energy Sciences, Division of Materials Science which supported this research under Award Number DESC0001912. The US-France collaboration was enabled through support from the Partnership University Fund (PUF).

\section{References}

[1] P. Simon, Y. Gogotsi, Nature Materials 7 (2008) 845.

[2] J.R. Miller, P. Simon, Science 321 (2008) 651

[3] V. Presser, M. Heon, Y. Gogotsi, Advanced Functional Materials 21 (2011) 810

[4] C. Portet, G. Yushin, Y. Gogotsi, Carbon 45 (2007) 2511.

[5] Y. Gao, Y.S. Zhou, M. Qian, X.N. He, J. Redepenning, P. Goodman, H.M. Li, L. Jiang, Y.F. Lu, Carbon 51 (2013) 52.

[6] S. Dörfler, I. Felhösi, T. Marek, S. Thieme, H. Althues, L. Nyikos, S. Kaskel, Journal of Power Sources 227 (2013) 218

[7] Y. Zhu, S. Murali, M.D. Stoller, K.J. Ganesh, W. Cai, P.J. Ferreira, A. Pirkle, R.M Wallace, K.A. Cychosz, M. Thommes, D. Su, E.A. Stach, R.S. Ruoff, Science 332 (2011) 1537.

[8] J. Chmiola, G. Yushin, Y. Gogotsi, C. Portet, P. Simon, P.L. Taberna, Science 313 (2006) 1760

[9] C.R. Pérez, S.-H. Yeon, J. Ségalini, V. Presser, P.-L. Taberna, P. Simon, Y. Gogotsi, Advanced Functional Materials 23 (2013) 1081.

[10] M. Arulepp, J. Leis, M. Lätt, F. Miller, K. Rumma, E. Lust, A.F. Burke, Journal of Power Sources 162 (2006) 1460.

[11] P.-C. Gao, Y. Lei, A.F.C. Pérez, K. Rajoua, D. Zitoun, F. Favier, Journal of Materials Chemistry 21 (2011) 15798.

[12] R. Liu, Y. Shi, Y. Wan, Y. Meng, F. Zhang, D. Gu, Z. Chen, B. Tu, D. Zhao, Journal of the American Chemical Society 128 (2006) 11652.

[13] A.V. Neimark, Y. Lin, P.I. Ravikovitch, M. Thommes, Carbon 47 (2009) 1617.

[14] Y. Gogotsi, P. Simon, Science 334 (2011) 917.

[15] A. Blyr, C. Sigala, G. Amatucci, D. Guyomard, Y. Chabre, J.-M. Tarascon, Journal of the Electrochemical Society 145 (1998) 194

[16] L. Wei, M. Sevilla, A.B. Fuertes, R. Mokaya, G. Yushin, Advanced Energy Materials 1 (2011) 356.

[17] D. Pech, M. Brunet, H. Durou, P. Huang, V. Mochalin, Y. Gogotsi, P.-L. Taberna, P. Simon, Nature Nanotechnology 5 (2010) 651.

[18] W. Gu, N. Peters, G. Yushin, Carbon 53 (2013) 292

[19] P.L. Taberna, P. Simon, J.F. Fauvarque, Journal of the Electrochemical Society 150 (2003) A292.

[20] R. Lin, P. Huang, J. Ségalini, C. Largeot, P.L. Taberna, J. Chmiola, Y. Gogotsi, P. Simon, Electrochimica Acta 54 (2009) 7025

[21] M. Kaempgen, C.K. Chan, J. Ma, Y. Cui, G. Gruner, Nano Letters 9 (2009) 1872.

[22] C.-M. Yang, Y.-J. Kim, M. Endo, H. Kanoh, M. Yudasaka, S. Iijima, K. Kaneko, Journal of the American Chemical Society 129 (2007) 20. 